Niniejsza publikacja jest dostępna na licencji Creative Commons. Uznanie autorstwa-Użycie niekomercyjne-Bez utworów zależnych 3.0 Polska. Pewne prawa zastrzeżone na rzecz autora. Zezwala się na wykorzystanie publikacji zgodnie z licencja - pod warunkiem zachowania niniejszej informacji licencyjnej oraz wskazania autora jako właściciela praw do tekstu. Treść licencji jest dostępna na stronie: http://creativecommons.org/licenses/by-nc-nd/3.0/pl/

Lingwistyka Stosowana 24: 4/ 2017, 83-94

\author{
Sławomir MACIEJEWSKI \\ Izabela GAWLOWICZ \\ Uniwersytet Zielonogórski
}

\title{
Współpracę kształtuje dialog - komunikowanie się związków zawodowych z pracownikami
}

\begin{abstract}
:
The Dialog Shapes the Cooperation - the Communication Between Union Trade and the Workers Authors emphasize the great importance of internal communication between trade unions and employee at the work place. Clarifying the nature of this process, the authors pay attention to its language's aspects and to its forms and scope. The classic tools used in this process such as: broadcasting center, wall newspaper, magazine works, newsletter, union's publications are highlighted. A special regard is dedicated to modern solutions such as internet, intranets, phone, SMS, MMS. The authors also point out the importance of the content in the communication between trade unions and employee, that addresses the issue of form, which should be used adequately to the information provided.
\end{abstract}

\section{Wstęp}

James Humes, pisarz i specjalista od przemówień prezydenckich stwierdził kiedyś, że sztuka komunikacji jest językiem przywództwa ${ }^{1}$. Funkcjonowanie jednostki w społeczeństwie, w grupach, w jakichkolwiek relacjach jest immanentnie związane z kreowaniem społecznego dialogu, czyli innymi słowy z komunikacją oraz komunikowaniem się. Szczególne jest znaczenie tej formy porozumiewania się i kształtowania tym samym własnego statusu w stosunkach prawnych. Wśród różnorodnych relacji społecznych dla niemal każdego z nas jedną z kluczowych jest relacja z pracodawcą, której jednym z ważnych elementów składowych jest (o ile jest) stosunek pracownika i związku zawodowego. W relacjach tego rodzaju język jest instrumentem, wykorzystywanym do komunikacji oraz komunikowania się. Stosunki prawne są regulowane obowiązującym prawem, zatem narzędziem służącym do komunikowania treści obowiązującego prawa jest język prawny. Język stosowany w relacji pracownik - związek zawodowy można określić jako pewien funkcjonalny styl języka ogólnego, zawierający elementy języka potocznego, prawnego oraz prawniczego.

\footnotetext{
${ }^{1}$ (http://www.freshbusinessthinking.com/the-art-of-communication-is-the-language-of-leadership/) (19.09.2017).
} 
Istnieje szereg łacińskich wyrazów zawierających rdzeń „communi”, który nawiązuje do przymiotnika „wspólny”, np.: commune (wspólny), communicabilis (przekazywalny), communicare (przekazywać), communicatio (jedność, przekaz, udział, zgodność), communis (wspólny), communitas (wspólnota) i in. Ponieważ wyraz może mieć więcej niż jedno znaczenie, dokonanie wyboru znaczenia adekwatnego w konkretnej sytuacji wymaga uwzględnienia kontekstu słownego, w jakim wyraz ten się znajduje (A. Choduń 2007: 14). Dla naszych rozważań istotne jest to, że terminy „komunikacja” oraz „komunikowanie się” w swojej warstwie znaczeniowej - jak wskazuje źródłosłów - nawiązują zarówno do przekazu, jak i do wspólnoty, ponieważ, w naszej opinii, efektywny przekaz i regularny dialog sprzyjają formowaniu wspólnoty. Naszym celem badawczym jest bowiem określenie czynników, w tym leksykalnych, niezbędnych w relacjach: związki zawodowe - pracownicy do kształtowania efektywnego dialogu, a w konsekwencji do współpracy tych podmiotów. Zakładamy, że właściwa interpretacja języka prawnego oraz adekwatne stosowanie języka prawniczego i potocznego są czynnikami stymulującymi i porządkującymi skuteczne porozumiewanie się. Bez dialogu trudno jest mówić o budowaniu przestrzeni, zwłaszcza wspólnej, opierającej się na jakichkolwiek normach postępowania, włączając w to normy prawne.

Punktem wyjścia do niniejszych rozważań jest przyjęcie, iż w relacjach między pracodawcą, a pracownikami nigdy nie będzie równowagi. Pozycja pracodawcy wobec pracownika zawsze jest nacechowana jego szczególnymi kompetencjami i w konsekwencji rolą, jaką odgrywa on w zakładzie pracy - naturalnie nadrzędną wobec pracownika. Kluczowym zadaniem związków zawodowych, stanowiącym również powód ich uformowania się w XVIII w. jest aktywność, mająca na celu korzystne (łagodzące wyżej wspomnianą nierównowagę) kształtowanie sytuacji pracowników w zakładzie pracy. Realizacja tego celu nie jest możliwa bez efektywnego porozumiewania się związków zawodowych z pracownikami oraz komunikowania pracodawcy w imieniu pracowników pewnych treści przez związki zawodowe. Rola związków zawodowych jako pośrednika w relacjach: pracodawca - pracownik jest uzasadniona konfrontacyjnym z natury kontekstem tej relacji.

Nasze rozważania mają na celu ustalenie, jakimi prawnymi i faktycznymi, formalnymi i nieformalnymi instrumentami komunikowania się z pracownikami posługuje się współczesny (nowoczesny) związek zawodowy, a jakich instrumentów w tych kontaktach używa pracownik i czy z punktu widzenia prawa i praktyki ich kompozycja i formuła są optymalne dla ich efektywności.

Niektóre przewidziane obowiązującym prawem instrumenty komunikacji i komunikowania się związków zawodowych z pracownikami mają tę charakterystyczną cechę, że funkcjonują dwupłaszczyznowo, tak w relacjach na linii: pracodawca $\leftrightarrow$ związki zawodowe (I. Gawłowicz/ S. Maciejewski 2017: 353 i nast.), jak i w perspektywie: pracownicy $\leftrightarrow$ związki zawodowe. Pobocznym celem naszej analizy jest zwrócenie uwagi na te aspekty komunikowania się związków zawodowych i pracowników, które w praktyce nie funkcjonują właściwie, a których zastosowanie mogłoby poprawić warunki pracy. 


\section{O „komunikacji” i „komunikowaniu się” raz jeszcze}

Absolutnie wyjątkową ludzką cechą jest zdolność porozumiewania się z innymi osobami i przekazywania informacji. Dzięki tej umiejętności możliwe jest tworzenie stosunków społecznych i grup. Żaden rodzaj współpracy, żadne struktury społeczne, ani stosunki pracy nie byłyby możliwe bez tej zdolności.

Stosunki pracy mają trudną i wielopłaszczyznową naturę, ponieważ uczestniczy w nich wiele różnorodnych podmiotów, przy czym podmioty te zwykle reprezentują odmienne interesy, ale równocześnie muszą ze sobą stale współpracować. Conditio sine qua non tej współpracy jest przede wszystkim wzajemne uznanie ich własnej podmiotowości, czego konsekwencją będzie dopiero efektywne porozumiewanie się. Rolę związków zawodowych w zakładzie pracy trzeba rozpatrywać w dwóch następujących perspektywach: związki, a pracodawca i związki, a pracownicy. Inną, równie ważną w zakładzie pracy płaszczyzną są stosunki między pracownikami i pracodawcą utrzymywane bez udziału związków zawodowych. Niniejsze rozważania poświęcamy drugiej z wymienionych relacji.

W polskim systemie prawnym podstawowym aktem prawnym regulującym stosunki pracy z uwzględnieniem praw i obowiązków pracowników oraz pracodawcy jest kodeks pracy z dnia 26 czerwca 1974 r. (Dz. U. 2016, poz. 1666), którego postanowienia stanowią zasadniczą część prawa pracy. Dla naszych rozważań istotne są także przepisy ustawy o związkach zawodowych z dnia 23 maja 1991 r (Dz. U. 2015 poz. 1881). Ustawodawca tworząc wymienione akty prawne skoncentrował się na relacjach między pracownikami i pracodawcą, włączając w to ich wzajemne obowiązki i uprawnienia oraz na stosunkach między związkami zawodowymi i pracodawcą. Pośredni pomiędzy wyżej wymienionymi obszar relacji, do którego tutaj się odnosimy, jest regulowany przepisami obowiązującego prawa raczej ogólnie i dość fragmentarycznie.

Narzędzia komunikowania się podmiotów stosunków pracy między sobą kształtuje obowiązujące prawo (formalne) oraz praktyka (nieformalne). Odmienna jest zatem ich natura, a ich skuteczność jest zdeterminowana przede wszystkim miarą upodmiotowienia pracownika w konkretnym zakładzie pracy. Specyficzna pozycja pracownika wobec pracodawcy jest znacznie silniejsza, gdy pracownika reprezentują aktywne i skuteczne związki zawodowe. Reprezentacja taka jest możliwa wyłącznie w warunkach stałego komunikowania się pracownika ze związkiem zawodowym oraz związku z pracownikiem i to na różnych płaszczyznach oraz różnymi metodami.

Porozumiewanie się pracowników i związków zawodowych jako pewien proces na trwałe wpisany w rzeczywistość zakładu pracy wypełnia kilka różnych funkcji, przy czym tylko niektóre z nich mają charakter mutualny. Jako pierwszą zdecydowanie wymienić należy funkcję informacyjną, ponieważ to ona jest dla tych relacji najbardziej charakterystyczna i wypełnia je treścią. Sens istnienia i działania związków zawodowych, ich ustawowe zadania sprawiają, że mamy tu do czynienia także z funkcją regulacyjną, ponieważ związki wspierane i informowane przez pracowników mogą realnie wpływać na formowanie obowiązujących w zakładzie pracy norm postępowania, a w szerszej skali - na kształtowanie i modyfikację prawa pracy poprzez opiniowanie projektów aktów prawnych. Jedną z ważniejszych funkcji kontaktów 
między pracownikami i związkami zawodowymi jest diagnozowanie zagrożeń, patologii, zjawisk niepożądanych w środowisku pracy, albo przeciwnie - ustalanie, co dla tego środowiska jest niezbędne, czy korzystne. W konsekwencji aktywny związek zawodowy taką diagnozę na bieżąco komunikuje pracodawcy i motywuje go do podjęcia pożądanych $\mathrm{w}$ tym wypadku działań. W takiej diagnostyce następuje także ewaluacja tego, co dla pracowników jest ważne, jakie wartości ich zdaniem powinny być przez pracodawcę szczególnie chronione; związek uzyskuje informacje o opinii pracowników na temat funkcjonowania zakładu pracy i ma możliwość prowadzenia negocjacji miedzy pracownikami a pracodawcą w sprawach konfliktowych.

\section{Zadania związków zawodowych w zakładzie pracy}

Stosownie do przepisów ustawy z dnia 23 maja 1991 r. związki zawodowe są dobrowolną i samorządną organizacją ludzi pracy, powołaną do reprezentowania i obrony ich praw, interesów zawodowych i socjalnych, niezależną od pracodawców, administracji państwowej i samorządu terytorialnego. Zadania, które w zakładzie pracy realizują zatem związki zawodowe to przede wszystkim: reprezentowanie praw pracowniczych, ochrona praw pracowniczych, monitorowanie przestrzegania w zakładzie pracy przepisów prawa pracy, dbanie o prawidłowe kształtowanie i stosowanie zasad wynagradzania i premiowania pracowników oraz zasad udzielania pomocy socjalnej, w efekcie - kształtowanie społecznych i prawnych stosunków pracy (tak w zakładzie pracy, jak i w szerszej skali). W specyficznym układzie podmiotów, uczestniczących w stosunkach pracy, koncentracja obowiązków związków zawodowych występuje w relacjach związków z pracodawcą oraz pracowników i pracodawcy. Natomiast obszar stosunków pracowników i związków zawodowych jest nacechowany dobrowolnością i współpracą, niekiedy nawet brakiem faktycznych dwustronnych kontaktów. Z tego względu obowiązujące prawo reguluje co do zasady obowiązki związków zawodowych oraz pracowników względem pracodawcy, obowiązki pracodawcy względem związków zawodowych i pracowników.

\section{Klasyczne narzędzia komunikacji w relacjach związku zawodowego z pracownikami}

Jedną z najprostszych form komunikacyjnych pomiędzy pracownikami, a związkiem zawodowym jest tablica ogłoszeniowa (gazetka ścienna), która znajduje się w najbardziej dostępnym dla wszystkich pracowników miejscu, przeważnie w okolicach wejścia, sekretariatu lub pomieszczenia socjalnego. W dobie ekranów plazmowych niektóre firmy wykorzystują je jako cyfrowe tablice ogłoszeniowe. $Z$ pewnością jest to najtańszy i najprostszy sposób informowania załogi. Oczywiście w relacjach pracownik-związek zawodowy narzędzie to wykorzystywane jest tylko dla prostych komunikatów lub ogłoszeń. Szybką, sprawną, w miarę tanią formą komunikacji jest newsletter czy biuletyn, który może przybierać nawet postać kartki papieru w formacie A4. Obecnie powielenie takiego materiału jest możliwe praktycznie w każdym zakładzie pracy. Taka metoda komunikacji sprawdza się w sytuacjach wymagających na- 
tychmiastowej reakcji, kiedy konieczne jest szybkie poinformowanie załogi o istotnych sprawach dla związku zawodowego, w przypadku których czas ma znaczenie lub zwłoka może wpłynąć na ich dezaktualizację lub utratę wartości.

Bardzo dobrą formą służącą do komunikacji jest gazetka zakładowa, zwana też gazetką przedsiębiorstwa czy firmową (zob. J. Bolek 2012: 139), a w sytuacji działających na terenie zakładu pracy kilku organizacji związkowych lub organizacji międzyzakładowych może to być branżowa gazetka związkowa. Gazetka publikowana przez związek zawodowy może być adresowana zarówno do związkowców, jak i innych współpracowników, podmiotów powiązanych lub klientów przedsiębiorstwa. Periodyczność jest uzależniona od ilości materiału informacyjnego, okoliczności oraz środków przeznaczonych na realizację tego przedsięwzięcia. W przypadku gazetki bardzo ważna jest jednak regularność jej ukazywania się. Jeśli czasopismo skierowane jest do załogi, należy dołożyć starań, by każdy pracownik otrzymał swój własny egzemplarz. Każdy pracownik dostaje taką samą precyzyjną informację. Istnieje możliwość przekazania obszernych wiadomości wraz z ilustracjami. Gazetka pomaga w działaniach integracyjnych załogi i identyfikacji pracowników ze związkiem zawodowym. Publikacje wewnętrzne pozwalają odbiorcom zapoznać się z informacjami w dowolnym czasie. Dzięki temu można się spodziewać, że poświęcą lekturze maksimum uwagi. W ten sposób rośnie szansa, że przeczytane informacje zostaną zrozumiane i przyswojone. Publikacje związkowe dodają przekazywanym informacjom prestiżu i splendoru, gdyż w świadomości każdego człowieka tkwi przekonanie o doniosłości „słowa drukowanego” (zob. J. Pruszyńska-Witkowska 2006: 113).

$\mathrm{W}$ relacjach związek zawodowy - pracownik istnieją jeszcze inne formy komunikacji, np. książka związkowa, czyli wydawnictwo zawierające wszystkie podstawowe i ważne informacje o związku. Otrzymuje ją każdy nowy członek związku zawodowego. Indywidualną formą komunikacji może być list przewodniczącego związku do pracownika. To narzędzie wykorzystywane jest przeważnie w przypadku nagan, pochwał lub okazji świątecznych albo jubileuszowych. Służy też motywowaniu zatrudnionych i budowaniu relacji pomiędzy związkiem zawodowym, a pracownikiem (zob. J. Trębacki 2006: 107-108).

Przechodząc do dalszych rozważań należy wspomnieć o pośrednim narzędziu komunikacji, łączącym klasyczne z nowoczesnymi urządzeniami komunikacyjnymi, tj. o telefonach, a zwłaszcza o telefonach komórkowych. W przypadku tych ostatnich istnieje możliwość wysyłania SMS (usługa przesyłania krótkich wiadomości tekstowych, możliwa do realizowania też w telefonii stacjonarnej) lub MMS (możliwość przesyłania multimediów, takich, jak grafika, animacje, wideoklipy, dźwięki itp.) (zob. J. Bolek 2012: 143). Telefony komórkowe są powszechniejsze, bardziej mobilne i tańsze, zarówno, jeśli chodzi o sprzęt, jak i koszty eksploatacji. W związku z powyższym, wyposażenie w nie pracowników jest w zakresie możliwości większości organizacji. W sytuacjach, gdy jednak nie jest to możliwe, można poprosić pracowników o udostępnienie ich prywatnych numerów telefonów. Wówczas jednak należy uwzględnić odmowę, którą trzeba uszanować. 


\section{Informowanie pracowników o działaniach związku - wewnętrzne sieci komunikacyjne}

Wykorzystywanie funkcjonalności stron internetowych do porozumiewania się wewnątrz organizacji i przekazu informacji w jej strukturach jest ważnym instrumentem w relacjach między pracownikami a związkami zawodowymi. Sieć komputerowa, funkcjonująca w obrębie jednego zakładu pracy, z której korzystają pracownicy tego zakładu określana jest jako intranet (czyli sieć wewnętrzna). Pełni ona - podobnie jak strona internetowa - funkcję informacyjną, ale w przeciwieństwie do strony web umożliwia rozsyłanie szczegółowych informacji dla wyselekcjonowanych adresatów $\mathrm{z}$ określoną regularnością. W praktyce intranet jest bardzo dobrym narzędziem informowania pracowników o działalności związkowej, ponieważ ułatwia system przekazu, skraca obieg informacji, a także daje możliwość modyfikowania przekazywanej treści na bieżąco. Intranet nie jest jednak wyłącznie „tablicą ogłoszeń”. W zależności od rodzaju wykorzystywanych aplikacji, może pełnić rolę interaktywnego narzędzia np. do prowadzenia przez związki zawodowe szkoleń (BHP, ppoż, przeciwdziałania wypaleniu zawodowemu i inne, przy uwzględnieniu odpowiednich metod weryfikacji odbycia szkoleń obowiązkowych) oraz warsztatów i do przypominania pracownikom o możliwości lub konieczności ich odbycia, do składania przez pracowników wniosków o pomoc (prawną, psychologiczną, socjalną), do opiniowania przez związki aktów prawnych wprowadzanych przez pracodawcę, do informowania przez związki zawodowe o działalności komisji pojednawczych, procedurach antymobbingowych, do monitorowania działań pracodawcy i informowania o nich pracowników zwłaszcza w sytuacjach przeprowadzania przez pracodawców zmian restrukturyzacyjnych i organizacyjnych, wreszcie do informowania o sprawach związkowych (związki działające w zakładzie pracy, liczba członków związku, wybory, zebrania, posiedzenia komisji zakładowych, sprawozdania z działalności).

Intranet jest nie tylko narzędziem przekazu informacji i konfrontowania opinii, przydatnym instrumentem w zakresie różnorodnej dokumentacji. Intranet jest także narzędziem zapewniania jawności w zakładzie pracy, ta z kolei służy budowaniu praworządności i wspólnoty (G. Domański et al. 2010).

\section{Komunikowanie się związków zawodowych z pracownikami przez pocztę elektroniczną}

Co do zasady kontakty związków zawodowych z pracownikami mogą odbywać się m.in. poprzez służbową pocztę elektroniczną. Jest to ważne narzędzie komunikowania pracownikom informacji związanych z aktywnością związków oraz otrzymywania od nich informacji o ich sytuacji w zakładzie pracy.

Trzeba jednak zawsze pamiętać o roli, jaką związki zawodowe spełniają w zakładzie pracy (specyficznej roli pośrednika między pracodawcą a pracownikami), ponieważ korzystanie przez nie z poczty elektronicznej w kontaktach z pracownikami może być w pewnych przypadkach niezgodne $\mathrm{z}$ wolą pracodawcy.

Jako właściciel adresu firmowego oraz firmowego komputera i innych urządzeń elektronicznych, służących do porozumiewania się w zakładzie pracy i stanowiących po prostu narzędzia pracy, pracodawca może określić zasady korzystania z nich (np. 
w formie regulaminu korzystania z nich). Pracodawca, limitując korzystanie ze służbowej poczty elektronicznej może kierować się zamiarem zapewnienia prawidłowego przebiegu pracy, w tym efektywnego wykorzystania czasu pracy (jeśli pracodawca np. twierdzi, że pracownicy otrzymują nadmiar różnorodnych wiadomości w sprawach, które nie dotyczą ich bezpośrednio, a jedynie angażują ich czas i uwagę, bądź jeśli pracodawca np. twierdzi, że związki zawodowe zakłócają spokój pracowników w środowisku pracy - np. rozsyłane przez związki zawodowe wiadomości prowadzą do skłócenia załogi).

\section{Diagnoza środowiska pracy w komunikacji związków zawodowych z pracownikami}

We wcześniejszych naszych rozważaniach (por. I. Gawłowicz/ S. Maciejewski 2017) o relacjach pracodawcy i związków zawodowych analizowaliśmy niezwykle przydatny instrument komunikowania się - konsultacje związków zawodowych z pracownikami, czyli związkowe konsultacje pracownicze (zob. J. Żołyński 2014, W. Kotowski/ B. Kurzępa 2015). Jest to jeden z tych instrumentów porozumiewania się, których wykorzystanie ma charakter wielopłaszczyznowy, ponieważ zasadniczo ich przeprowadzenie służy postawieniu przez związek ogólnej lub szczegółowej diagnozy w sprawach funkcjonowania poszczególnych jednostek zakładu pracy i w ogólności stanu zakładu pracy. Konsultacje pracownicze są ważnym instrumentem monitorowania sytuacji w zakładzie pracy, od określenia jego słabych i mocnych punktów, poprzez diagnozę zagrożeń i szans, relacji służbowych między samymi pracownikami - przeprowadzane regularnie są szansą na zbudowanie realnej płaszczyzny porozumienia z pracodawcą. Warunkiem, jaki musi być spełniony, by konsultacje mogły pełnić taką rolę, jest właściwa postawa pracodawcy, który z konsultacji czerpie takie same informacje, jak związek zawodowy. Jeśli pracodawca instytucji konsultacji nie traktuje jako aktu wrogości wobec niego, czy wręcz sabotażu, konsultacje będą działały na korzyść wszystkich. Związki dzięki konsultacjom poprawiają przepływ informacji w zakładzie pracy, sygnalizują słabe i mocne strony zakładu pracy, potrzeby i szanse. Z punktu widzenia pracowników konsultacje spełniają rolę niebagatelną - budują ich podmiotowość, wzmacniają ich pozycję w zakładzie pracy, dają im poczucie wspólnotowości. Podstawy prawne dla konsultacji znajdziemy w aktach prawa międzynarodowego - Europejska Karta Społeczna w art. 6 ust. 1 zobowiązuje państwa do promowania wspólnych konsultacji między pracownikami i pracodawcami, do popierania dobrowolnych między nimi negocjacji oraz do popierania tworzenia i stosowania mechanizmów pojednawczych między tymi podmiotami. Konwencja o Ochronie Praw Człowieka i Podstawowych Wolności z dnia 4 listopada 1950 r. w swoim art. 10 oraz Międzynarodowy Pakt Praw Cywilnych i Politycznych z dnia 16 grudnia 1966 r. w swoim art. 19 gwarantują osobom fizycznym podległym jurysdykcji państw - stron Konwencji wolność ekspresji, podobnie czyni Konstytucja RP z dnia 2 kwietnia 1997 r., która zapewnia obywatelom RP oraz innym osobom podległym jurysdykcji państwa polskiego w swoim art. 54 wolność wyrażania poglądów oraz pozyskiwania i rozpowszechniania informacji. Państwo, na którym spoczywa obowiązek umożliwienia związkom zawodowym prowadzenia akcji związkowej, dysponuje swobodą 
wyboru co do tego, w jaki sposób zapewnić związkom zawodowym wysłuchanie. Polski ustawodawca nie zastosował ograniczeń prawa pracowników do konsultowania się ze związkami zawodowymi, wręcz przeciwnie, kodeks pracy zobowiązuje do dialogu ze związkami zawodowymi i poprzez nie do dialogu z pracownikami z dnia 26 czerwca 1974 r. m. in. w swoim art. 23.

\section{Partnerstwo to pochodna dialogu, wolności i jawności}

Zakład pracy jest z założenia wspólnotą. Poza tym, że ludzie w nim pracują, to także nawiązują w nim kontakty, przeżywają szereg emocji, także związanych z osobą pracodawcy. Kształtowanie takiej wspólnoty wymaga komunikowania się pracodawcy ze związkiem zawodowym i wiedzy pracowników o tym, co się dzieje w zakładzie pracy, wymaga regularnego dialogu, odpowiedzialności i przejrzystości. Zapewnienie jawności, będącej konsekwencją realizacji prawa do informacji jest trudne, ale ustala na odpowiednim poziomie relacje w zakładzie pracy, pomaga budować kulturę dialogu, zmniejsza szanse skonfliktowania się załogi, poprawia reprezentację interesów różnych stron, daje pracownikom gwarancję wywierania realnego wpływu na środowisko pracy, buduje praworządność i wspólnotę, wzmacnia poczucie odpowiedzialności.

Pisaliśmy wcześniej o wadach, jakie jawność może mieć dla pracodawcy - podobne może mieć dla związku zawodowego, który niejednokrotnie dysponuje pewnymi uprawnieniami mogącymi poprawić choćby sytuację socjalną konkretnych pracowników (I. Gawłowicz/ S. Maciejewski 2017). Jawność weryfikuje w oczach pracowników aktywność związku zawodowego, ujawnia jego długo i krótkofalowe cele, motywuje go do przestrzegania prawa, ogranicza ryzyko działań niezgodnych z prawem czy zmierzających do jego obejścia, wymusza ponoszenie odpowiedzialności za działania związku i za jego bezczynność. Jawność w zakładzie pracy zapewnia wspomniany już wcześniej intranet, protokoły z posiedzeń organów kolegialnych, udział przedstawicieli związków zawodowych $\mathrm{w}$ organach kolegialnych, udział przedstawicieli związków zawodowych w podejmowania decyzji ważnych dla zakładu pracy i pracowników, negocjacje płacowe, negocjacje co do sposób korzystania z zakładowego funduszu świadczeń pracowniczych.

Efektywność komunikowania się pracowników i związków zawodowych wpływa również na przydatność związków w sferze legislacyjnej - ich działalność na rzecz przyjmowania pewnych rozwiązań prawnych w zakresie ochrony pracowników oraz rozwijania prawa pracy nie ma racji bytu bez regularnego kontaktu z pracownikami. Im więcej związki wiedzą o problemach pracowniczych, tym większa szansa na ich działania na rzecz poprawy obowiązujących regulacji prawnych.

Stosowanie narzędzi komunikacji w relacjach pracownik - związek zawodowy musi być spójne i skoordynowane na trzech płaszczyznach: treści, formy i czasu. Komunikaty przekazywane za pomocą różnych instrumentów powinny być jednorodne i w żadnym wypadku nie mogą sobie zaprzeczać. Jeśli sytuacja wymaga zróżnicowania komunikatów w zależności od odbiorców, istnieje możliwość dostosowania języka do zdolności percepcyjnych adresatów. W celu ułatwienia komunikacji należy również zadbać o formę. Warto, by była ona czytelna, przejrzysta, a w przypadku 
elektronicznych narzędzi miała również intuicyjne menu. Stosowanie podobnych rozwiązań graficznych wzmacnia u odbiorcy wrażenie spójności przekazu. W przypadku posługiwania się więcej niż jednym narzędziem dla przekazania danego komunikatu, konieczne jest skoordynowanie działań w taki sposób, aby w pierwszej kolejności informacja trafiła do odbiorców za pośrednictwem instrumentów o największym zasięgu i największej sile oddziaływania (zob. J. Grzenia 2007).

\section{Uwagi końcowe}

Reasumując rozważania w przedmiocie współpracy i komunikowania się na płaszczyźnie związek zawodowy - pracownicy (nie tylko członkowie związku) należy zaznaczyć, że na postawy pracowników, zwłaszcza w dużych zakładach pracy, duży wpływ mają liderzy związkowi. Powszechne mniemanie o liderach związków zawodowych jest dość stereotypowe i niestety pejoratywne. Mają na to wpływ różnorodne postawy liderów. Aby utrzymać się na związkowym etacie, liderom zdarza się podejmowanie działań destrukcyjnych: wysuwają irracjonalne żądania socjalne, usiłują wpływać na zarządzanie firmą po to tylko, by zapewnić sobie popularność wśród szeregowych członków związku. Zdarza się, że ich aktywność staje się przyczyną poważnych kłopotów firmy i w konsekwencji negatywnie wpływa na los pracowników. Im mniej pracownicy wiedzą o swojej firmie i planach jej kierownictwa, tym bardziej są podatni na manipulacje, a te mogą być dziełem liderów związkowych. Niedoinformowani pracownicy przyjmują bezkrytycznie informacje mówiące o złych intencjach kierownictwa zakładu pracy, o rzekomych malwersacjach, zagrożeniu miejsc pracy itp. $Z$ tego powodu omawiana przez nas wcześniej jawność i mechanizmy jej zapewniania w zakładzie pracy odgrywają bardzo ważną i nie jedynie informacyjną rolę stanowią bowiem podstawę budowania relacji opartych na zaufaniu w środowisku pracy. Model przywództwa w związkach zawodowych jest natomiast drugim ważnym filarem takich relacji - w zakładach pracy potrzebni są nowocześni, aktywni i odważni liderzy związków zawodowych, rzetelni, wiarygodni, otwarci i gotowi na zmiany, ze społecznikowskim zacięciem, cieszący się szacunkiem (aczkolwiek niekoniecznie sympatią) pracodawcy i pracowników. Aby pracownicy traktowali związki zawodowe jako swego partnera (sojusznika) w zakładzie pracy, liderzy związków muszą reprezentować model przywództwa jutra.

W środowisku pracy w pewnym stopniu znajdujemy odzwierciedlenie pewnych patologicznych zjawisk sceny politycznej i gospodarczej i to one mogą stymulować u pracowników postawę typu „spodziewajmy się najgorszego", nadto resztki mentalności społeczeństwa postkomunistycznego wytwarzają niekiedy zaskakujący sposób odbierania informacji, tj. paradoksalnie informacja o niepomyślnym obrocie spraw może być odbierana jako dobra wiadomość i choćby była absurdalna, miewa pewien stopień wiarygodności (zob. P. Bielawski 2011: 89).

Stała, efektywna współpraca i regularny dialog związku zawodowego z pracownikami może chronić przed uleganiem negatywnym mechanizmom. Wymaga to jednak zaangażowania wszystkich stron, uprawnionych do tego dialogu, jego rzeczywistego, codziennego uprawiania (nie tylko w sytuacji zagrożenia), rozwijania form ko- 
munikacji i ciągłego poszukiwania tych najbardziej efektywnych. Trzeba w tym miejscu podkreślić rolę języka komunikacji werbalnej i to, jak istotna jest jego precyzja, perswazyjność, przystępność, dbałość o jego czytelność. Trzeba przy tym wziąć pod uwagę fakt, że domeną działania związków zawodowych jest komunikacja wewnętrzna wspomagana niekiedy przez aktywność w społecznych środkach przekazu. Dość często zdarza się, że informacje i opinie przekazywane przez związki zawodowe wyprzedzają komunikaty wysyłane przez zakład pracy. Dzieje się tak przede wszystkim dlatego, że związki zawodowe są równocześnie decydentami i nadawcami swoich informacji, więc komunikaty pracodawcy będą zwykle spóźnione, a inicjatywa informacyjna pozostanie po stronie związków.

W przeciwieństwie do naszych wcześniejszych rozważań, odnoszących się do relacji między związkiem zawodowym i pracodawcą (I. Gawłowicz/ S. Maciejewski 2017), niniejsze przemyślenia jedynie w bardzo niewielkim stopniu możemy oprzeć na istniejącym orzecznictwie. W sądach krajowych najczęściej występujący problem prawny z udziałem związków zawodowych i pracownika dotyczy sytuacji, w której z pracownikiem, objętym ochroną związku zawodowego zostaje rozwiązana umowa o pracę (za wypowiedzeniem lub bez) mimo takiej ochrony (np. orzeczenie Sądu Najwyższego z dnia 15 marca 2006 r., sygn. akt II PK 127/05, w którym Sąd Najwyższy wskazał, że rozwiązanie umowy z pracownikiem, który dopuścił się ciężkiego naruszenia obowiązków pracowniczych mimo braku zgody związków zawodowych jest wbrew przepisom o szczególnej ochronie pracowników będących działaczami związkowymi), bądź niezawiadomienia zakładowej organizacji związkowej o zamiarze wypowiedzenia umowy o pracę (np. uchwały Sądu Najwyższego z 24 stycznia 2012 r., PZP 7/11, z 14 czerwca 2012 r., I PK 231/11, z 21 listopada 2012 r., III PZP 6/12). Jeśli chodzi o sądy międzynarodowe, to np. w orzeczeniach Europejskiego Trybunału Praw Człowieka kwestia stosunków między pracownikami i związkami zawodowymi pojawia się rzadko i jedynie w kontekście incydentalnej między tymi podmiotami współpracy, zazwyczaj na tle korzystania przez pracowników z wolności słowa oraz domniemanego naruszenia przez nich obowiązku dbałości o dobre imię pracodawcy (tak np. w sprawie Heinish przeciwko Niemcom, skarga nr 28274/08, gdzie zwolniona dyscyplinarnie z pracy pielęgniarka podjęła współpracę ze związkami zawodowymi w celu ujawnienia rzeczywistych powodów jej zwolnienia, a Trybunał uznał takie działalnie za prawidłowe korzystanie z wolności słowa: orzeczenie z dnia 21 lipca 2011 r. Problem o innym charakterze powstał w sprawie Palomo Sànchez i inni przeciwko Hiszpanii, skargi nr 28955/06, 28957/06, 28959/06, 28964/06, gdzie pracownicy, członkowie związku zawodowego publikowali gazetkę, w której w sposób obraźliwy krytykowali pracodawcę i w efekcie pracodawca rozwiązał z nimi umowę o pracę - Trybunał w tej sprawie wskazał na potrzebę oddzielenia wypowiedzi krytycznych od obraźliwych, wskazał, że wolność wypowiedzi nie ma charakteru nieograniczonego, zwłaszcza, gdy w grę wchodzą prawa i wolności innych osób; Trybunał podkreślił także, że stosunki pracy w dużej mierze powinny być oparte na wzajemnym zaufaniu i jakkolwiek nieracjonalnym byłoby wymagać od pracownika bezwzględnej lojalności, to jednak brak szacunku i wypowiedzi obraźliwe uzasadniają zastosowanie nawet surowych sankcji. Trybunał w sprawie Palomo Sànchez i inni przeciwko Hiszpanii nie uznał działania państwa za naruszenie wolności słowa, orzeczenie Wielkiej 
Izby z dnia 12 września 2011 r.).

Obszar komunikacji i komunikowania się między związkami zawodowymi i pracownikami jest regulowany ogólnymi przepisami w zakresie prawa pracy, ochrony danych osobowych i ochrony dóbr osobistych, we fragmentarycznym natomiast orzecznictwie sądów krajowych i międzynarodowych trudno byłoby szukać formowania standardów postępowania w tej sferze. Tym bardziej jest to obszar godny zainteresowania i działania prawników, językoznawców, specjalistów od public relations. Jesteśmy przekonani, że dbałość o poziom kultury organizacyjnej i prawnej w zakładzie pracy ma swój początek w umiejętnym posługiwaniu się językiem jako narzędziem komunikacji.

\section{Bibliografia}

Bielawski, P. (2011), Public relations: zarzadzanie informacjami. Opole.

Bolek, J. (2012), Efektywne wykorzystywanie klasycznych i nowoczesnych narzędzi komunikacji wewnętrznej przez przedsiębiorstwo, (w:) W. Harasim (red.), Zarządzanie kapitałem intelektualnym w organizacji inteligentnej. Warszawa, 133-151.

Choduń, A. (2007), Stownictwo tekstów aktów prawnych w zasobie leksykalnym współczesnej polszczyzny. Warszawa.

Gawłowicz, I./ S. Maciejewski (2017), Wybrane elementy komunikowania się zwiąków zawodowych z pracodawca, (w:) J. Alnajjar (red.), Komunikacja w organizacjach. Saarbrucken, 353-377.

Grzenia, J. (2007), Komunikacja językowa w Internecie. Warszawa.

Kotowski, W./ B. Kurzypa (2015), Zwiazki zawodowe. Komentarz do ustawy o zwiazkach zawodowych. Warszawa.

Pruszyńska-Witkowska J. (2006), Komunikacja wewnętrzna, (w:) B. Janiszewska (red.), Sztuka public relations. Z doświadczeń polskich praktyków. Warszawa, $110-121$.

Domański Zakrzewski Palinka Sp.k. i Kolibro Sp. z o.o. (2010), Intranet a prawo, Vademecum dla, managerów, redaktorów i administratorów Intranetu. Warszawa

Trębacki, J. (2006), Relacje wewnętrzne, (w:) J. Olędzki/ D. Tworzydło (red.), Public relations. Znaczenie społeczne i kierunki rozwoju. Warszawa, 107-108.

Żołyński, J., (2014), Ustawa o związkach zawodowych, komentarz. Warszawa. (URL http://www.freshbusinessthinking.com/the-art-of-communication-is-thelanguage-of- leadership/). [Pobrano 19.09.2017].

\section{Akty prawne}

Konwencja o Ochronie Praw Człowieka i Podstawowych Wolności z dnia 4 listopada 1950 r., Dz. U. 1993, nr 61, poz. 284 ze zm.

Europejska Karta Socjalna z dnia 18 października 1961 r.,Dz. U. 1999, nr 8, poz. 67 ze zm.

Międzynarodowy Pakt Praw Cywilnych i Politycznych z dnia 16 grudnia 1966 r., Dz. U. 1977, nr 38, poz. 167.

Konstytucja RP z dnia 2 kwietnia 1997 r., Dz. U. 1997, nr 78, poz. 483 ze zm. 
Ustawa z dnia 7 kwietnia 1989 r. prawo o stowarzyszeniach, Dz. U. 1989, nr 20, poz. $104 \mathrm{ze} \mathrm{zm}$.

Ustawa z dnia 23 maja 1991 r. o związkach zawodowych, Dz. U. 2015 poz. 1881 tekst jednolity.

Ustawa z dnia 26 czerwca 1974 r. Kodeks pracy, Dz. U. 2016, poz. 1666 ze zm.

\section{Orzecznictwo}

Heinish przeciwko Niemcom, skarga nr 28274/08, orzeczenie ETPC z dnia 21 lipca $2011 \mathrm{r}$.

Palomo Sànchez i inni przeciwko Hiszpanii, skargi nr 28955/06, 28957/06, 28959/06, 28964/06, orzeczenie Wielkiej Izby z dnia 12 września 2011 r.

Orzeczenie Sądu Najwyższego z dnia 15 marca 2006 r., II PK 127/05, LEX nr 277809.

Uchwała Sądu Najwyższego z dnia 24 stycznia 2012 r., PZP 7/11.

Uchwała Sądu Najwyższego z dnia 14 czerwca 2012 r., I PK 231/11.

Uchwała Sądu Najwyższego z dnia 21 listopada 2012 r., III PZP 6/12. 